\title{
Protective effect of Enhydra fluctuans DC. aerial against insulitis in alloxan-induced diabetic rats
}

\author{
Rina DELFITA ${ }^{1,2}$ (D), Dahelmi DAHELMI 2 (D), Djong Hon TJONG ${ }^{2 *} \mathbb{D}$, Suhatri SUHATRI ${ }^{3}$ \\ 1 Department of Biology Education, Faculty of Tarbiyah and Teacher Training, Institut Agama Islam Negeri (IAIN) \\ Batusangkar, West Sumatra, Indonesia. \\ 2 Department of Biology, Faculty of Mathematics and Natural Science, Andalas University, West Sumatra, Indonesia. \\ 3 Department of Pharmacy, Andalas University, West Sumatra, Indonesia. \\ * Corresponding Author. E-mail: djonghontjong@sci.unand.ac.id (D.H.T.); Tel. +62-0751-777427.
}

Received: 19 May 2021 / Revised: 30 September 2021 / Accepted: 12 December 2021

\begin{abstract}
This study aimed to assess the protective effect of the n-hexane fraction of Enhydra fluctuans aerial against insulitis in alloxan-induced diabetic rats. A total of 30 male rats (five normal rats and 25 diabetic rats) were assigned to one of six groups ( $n=5$ /groups): group 1 is the normal rat group (GN) was without treatment, group 2 is diabetic rat was given $0.5 \% \mathrm{Na}-\mathrm{CMC}(\mathrm{G} 0)$, group 3 is diabetic rat was given glibenclamide $0.45 \mathrm{mg} / \mathrm{kg}$ body weight (G1), group 4 , 5 , and 6 are diabetic rats were given n-hexane fraction doses of 57.03, 114.06, and $171.09 \mathrm{mg} / \mathrm{kg}$ body weight respectively. The experiment was carried out over 21 days. Blood glucose was measured on the first and latest day of treatment. Furthermore, insulin levels, the number of pancreatic $\beta$-cell, and degrees of insulitis were evaluated. The nhexane fraction reduced blood glucose, increased insulin levels, and increased the number of pancreatic $\beta$-cell significantly in alloxan-induced diabetic rats. The administration of the n-hexane fraction at a dose of $57.03 \mathrm{mg} / \mathrm{kg}$ body weight exerted the best protective effect against insulitis and promoted regeneration of the islet of Langerhans. The results of this study indicate that this herb could effectively reduce insulitis and promote the regeneration of pancreatic tissue under diabetes. Thus, E. fluctuans has the potential to be developed as a novel diabetes drug.
\end{abstract}

KEYWORDS: Alloxan; antidiabetes; Enhydra fluctuans; hyperglycemia; insulitis.

\section{INTRODUCTION}

Insulitis is identified by pancreatic $\beta$-cell damage and is directly involved in the pathogenicity of diabetes [1-2]. In insulitis conditions, proinflammatory cytokines such as tumor necrosis factor- $\alpha$ (TNF- $\alpha$ ), interleukin-1 $\beta$ (IL1 $\beta)$, and interferon- $\gamma$ (IFN- $\gamma)$ are abundant in the islets of Langerhans [1]. Proinflammatory cytokines contribute to the cytotoxicity of pancreatic $\beta$-cells [1,3-4]. Therefore, drugs that have the activity of reducing insulitis and ameliorating pancreatic $\beta$-cells are expected to be highly effective in controlling of diabetes.

The drugs used in diabetes management have not fully succeeded in protecting and ameliorating the pancreas [5]. Information about the antidiabetic activity of plant extracts has been widely reported, but their effect on reducing insulitis is very limited [3]. Thus, studies on drugs that have activity of reducing and ameliorating the pancreas of diabetics are urgently needed [2, 6, $7-8]$. Among various sources of drugs for diabetes, traditional medicinal plants are widely explored including in Indonesia. Many medicinal plants are known to contain compounds exerting various underlying mechanisms [9-10] and are relatively minimum of side effects [11-12]. One of Indonesia's traditional medicinal plants is Enhydra fluctuans.

E. fluctuans DC. (English-Buffalo Spinach, Hindi-Haruch, Indonesia-Godobos, Cikarau) is a semiaquatic herb belonging to the Asteraceae family, usually found near springs in West Sumatra, Indonesia. This herb is a traditional medicinal plant for the Minangkabau tribe of West Sumatra and is consumed as a vegetable. This herb is known to have broad biological activities such as having antidiabetic activity [13-14], hepatoprotective [15] and antioxidants [16-18]. It is also known to be rich in nutrients, containing triterpenoids, flavonoids, phenols, and steroids [17-19].

How to cite this article: Delfita, D, Dahelmi, D, Tjong, DH, Suhatri, S. Protective effect of Enhydra fluctuans DC. aerial against insulitis in alloxaninduced diabetic rats. J Res Pharm. 2022; 26(1): 180-188. 
The glucose-lowering effects of ethanol extract from this herb have been reported in experimental animals [13-14]. However, its effect on protecting the pancreas and reducing insulitis has not been discussed. This study focused on evaluating the protective effect of the n-hexane fraction of E. fluctuans aerial against insulitis in alloxan-induced diabetic rats. Our results demonstrate a promising beneficial effects of this herb against diabetes.

\section{RESULTS}

\subsection{Effect of $\mathbf{n}$-hexane fraction of E. fluctuans aerial on blood glucose level}

Alloxan administration caused the rat to become diabetic, which was characterized by high blood glucose levels. The initial average of the blood glucose level of the rats before diabetic induction was $75.00 \pm$ $8.86 \mathrm{mg} / \mathrm{dL}$, while after alloxan administration it was $387.60 \pm 25.79-479.00 \pm 43.75 \mathrm{mg} / \mathrm{dL}$ (increased 5-6 times the normal rat blood glucose level) (Table 1). Hence, the blood glucose criteria for diabetic rats met the requirements for antidiabetic testing because the blood glucose level was in state hyperglycemia (above 350 $\mathrm{mg} / \mathrm{dL}$ ). The administration of n-hexane fraction caused blood glucose reduction in diabetic rats, where the dose of $57.03 \mathrm{mg} / \mathrm{kg}$ body weight (G2) showed the highest reduction and was significantly different $(P<0.05)$ as compared with negative control (G0) but remained comparable with glibenclamide (G1; $P>0.05)$. It suggests that the n-hexane fraction exerted an antidiabetic activity with an equal activity as glibenclamide (G1) particularly at a dose of $57.03 \mathrm{mg} / \mathrm{kg}$ body weight (G2).

Table 1. Effect of n-hexane fraction of E. fluctuans aerial on blood glucose levels.

\begin{tabular}{|c|c|c|c|}
\hline Group treatment & Day 0 & Day 21 & $\begin{array}{l}\text { Percentage of blood } \\
\text { glucose reduction }(\%)\end{array}$ \\
\hline GN (Normal group) & $73.20 \pm 3.70$ & $75.00 \pm 8.86$ & - \\
\hline G0 (Negative control) & $387.60 \pm 25,79$ & $445.00 \pm 44.41 \mathrm{a}$ & - \\
\hline G1 (Positive control) & $416.20 \pm 27.90$ & $184.60 \pm 45.55^{c}$ & $58.52 \pm 10.23$ \\
\hline $\begin{array}{l}\mathrm{G} 2(57.03 \mathrm{mg} / \mathrm{kg} \text { body weight } \\
\text { of n-hexane fraction) }\end{array}$ & $479.00 \pm 43.75$ & $132.80 \pm 22.87 \mathrm{c}$ & $70.15 \pm 5.12$ \\
\hline $\begin{array}{l}\text { G3 }(114.06 \mathrm{mg} / \mathrm{kg} \text { body weight } \\
\text { of n-hexane fraction) }\end{array}$ & $434.80 \pm 41.99$ & $266.60 \pm 48.90^{\mathrm{bc}}$ & $64.94 \pm 1.09$ \\
\hline $\begin{array}{l}\mathrm{G} 4(171.09 \mathrm{mg} / \mathrm{kg} \text { body weight } \\
\text { of n-hexane fraction) }\end{array}$ & $433.00 \pm 28.88$ & $355.00 \pm 58.83 \mathrm{ab}$ & $20.22 \pm 13.22$ \\
\hline
\end{tabular}

\subsection{Effect of $\mathbf{n}$-hexane fraction of $E$. fluctuans aerial on insulin level}

Plasma insulin levels were determined after 21 days n-hexane fraction of E. fluctuans aerial treatment (Table 2). Our data indicate that the insulin level of diabetic rats in G2 treatment ( $57.03 \mathrm{mg} / \mathrm{kg}$ body weight) was significantly different $(P<0.05)$ as compared with negative controls $(\mathrm{G} 0)$ and was comparable with insulin level in normal rats. Moreover, the insulin level of G2 was also higher and not significantly different $(P<0.05)$ when compared with G1 (glibenclamide-treated group). The n-hexane fraction has active compounds that have the activity of stimulating insulin secretion, resulting in high insulin levels in the blood. Insulin facilitates the use and uptake of glucose by the liver and muscles, resulting in reduced blood glucose in diabetic rats.

\subsection{Effect of $\mathbf{n}$-hexane fraction of E. fluctuans aerial on the histological structure of islet of Langerhans}

Histological observation on pancreatic tissues expectedly revealed a salient impairment in islet of Langerhans of alloxan-induced diabetic rats. Such impairments were indicated by pycnotic nuclei, a decrease in the number of $\beta$-cells, necrosis, hyalinization, and fibrosis (Figure 1). Otherwise, administration of the nhexane fraction for 21 showed improvements in the islets as profoundly observed at a dose of $57.03 \mathrm{mg} / \mathrm{kg}$ body weight (G2) (Figure 1D). Moreover, this group was also had lesser necrosis in the islets. It is known that the administration of the n-hexane fraction of E. fluctuans aerial has the activity of ameliorating islet of Langerhans from damage caused by alloxan and high blood glucose toxicity. 
Table 2. Effect of n-hexane fraction of E. fluctuans aerial on insulin levels after 21 days of treatment.

\begin{tabular}{lc}
\hline Group of treatment & Insulin level (mIU/L) \\
\hline GN (Normal group) & $2.09 \pm 0.27 \mathbf{a}$ \\
G0 (Negative control) & $1.59 \pm 0.03 \mathbf{b}$ \\
G1 (Positive control) & $1.77 \pm 0.06^{\mathrm{ab}}$ \\
G2 (57.03 mg/kg body weight of n-hexane fraction) & $1.99 \pm 0.05^{\mathbf{a}}$ \\
G3 $(114.06 \mathrm{mg} / \mathrm{kg}$ body weight of n-hexane fraction) & $1.87 \pm 0.06^{\mathbf{a}}$ \\
G4 (171.09 mg/kg body weight of n-hexane fraction) & $1.83 \pm 0.04 \mathrm{ab}$ \\
\hline
\end{tabular}

According to Duncan's New Multiple Range Test $(\mathrm{P}<0.05)$, a different letter in the same column indicates a significant difference versus negative control.
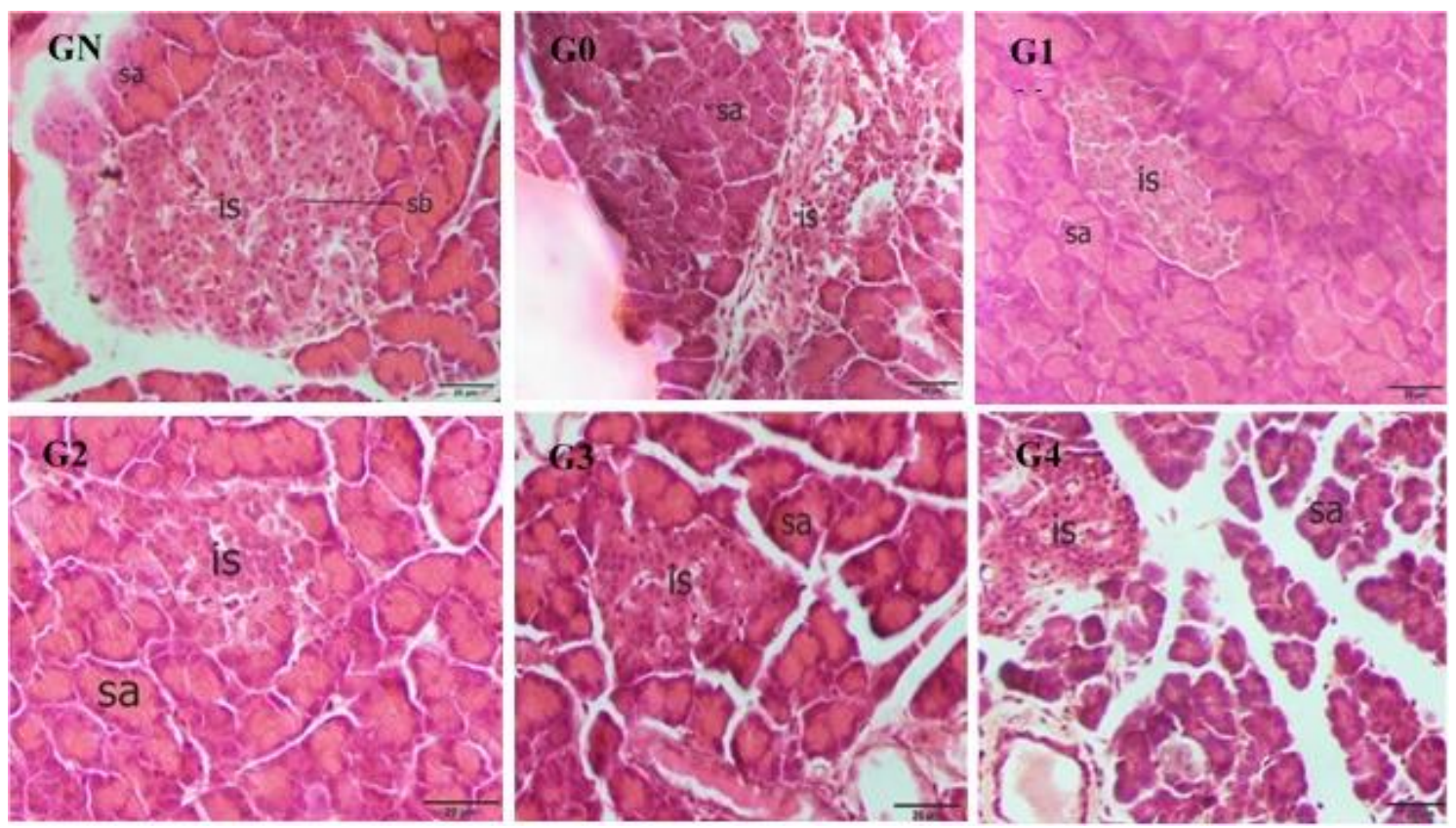

Figure 1. Histological structures of pancreas of rats after being treated with n-hexane fraction E. fluctuans aerial for 21 days. GN (Normal Group), G0 (Negative Control Diabetic Group), G1 (Diabetic + Glibenclamide), G2 (Diabetic $+57.03 \mathrm{mg} / \mathrm{kg}$ body weight of n-hexane fraction), G3 (Diabetic $+114.06 \mathrm{mg} / \mathrm{kg}$ body weight of n-hexane fraction), G4 (Diabetic $+171.09 \mathrm{mg} / \mathrm{kg}$ body weight of $\mathrm{n}$-hexane fraction). is. islet of Langerhans; sa. acinar cells. Magnification 400x.

Table 3. Effect of n-hexane fraction of E. fluctuans aerial on the number of pancreatic $\beta$-cells after 21 days of treatment.

\begin{tabular}{ll}
\hline Group treatment & Count of $\beta$-cells \\
\hline GN (Normal Group) & $625.00 \pm 43.57$ \\
G0 (Negative control) & $280.20 \pm 10.54^{\mathbf{c}}$ \\
G1 (Positive control) & $315.20 \pm 5.45^{\mathbf{b}}$ \\
G2 (57.03 mg/kg bw of n-hexane fraction) & $471.80 \pm 4.68^{\mathbf{a}}$ \\
G3 (114.06 mg/ $\mathrm{kg}$ bw of n-hexane fraction) & $343,20 \pm 8.56 \mathbf{b}$ \\
G4 (171.09 mg/kg bw of n-hexane fraction) & $344,60 \pm 16.41^{\mathbf{b}}$ \\
\hline
\end{tabular}

According to Duncan's New Multiple Range Test $(\mathrm{P}<0.05)$, a different letter in the same column indicates a significant difference vesus negative control.

We also counted the number of pancreatic $\beta$-cells as presented in Table 3. The number of diabetic rat's pancreatic $\beta$-cells was decreased when compared with the normal group (the reduction ranged from 0.5 to 2.5 times the number of normal rats $\beta$-cells). Furthermore, administration of $n$-hexane fraction increased the number of pancreatic $\beta$-cells of diabetic rats with the highest increase was observed in G2 $(57.03 \mathrm{mg} / \mathrm{kg}$ body weight) and it was significantly different as compared with other diabetic groups. Thus, the administration of the n-hexane fraction of E. fluctuans aerial especially the dose of $57.03 \mathrm{mg} / \mathrm{kg}$ body weight (G2), has the activity of ameliorating islets of Langerhans and increasing the number of $\beta$-cells of the pancreas. 
Insulitis score was calculated based on the degree of leukocyte infiltration in the islet of Langerhans. Our data demonstrated that diabetic rats had mild, moderate insulitis and complete insulitis. In non-treated diabetic rats (G0) and glibenclamide-treated diabetic rats (G1), the percentage of normal islet of Langerhans was lower, while complete and moderate insulitis cases were higher compared with other groups (Figure 2). Moreover, the percentage of moderate and total insulitis cases were higher compared to mild and severe insulitis cases suggesting severe damage in the islet of Langerhans of alloxan-induced diabetic rats. Administration of n-hexane fraction E. fluctuans aerial orally for 21 days caused a reduction in insulitis with the percentage of reductions of insulitis varied depending on the dose of the fraction. The highest percentage in all categories of insulitis was found in G2.

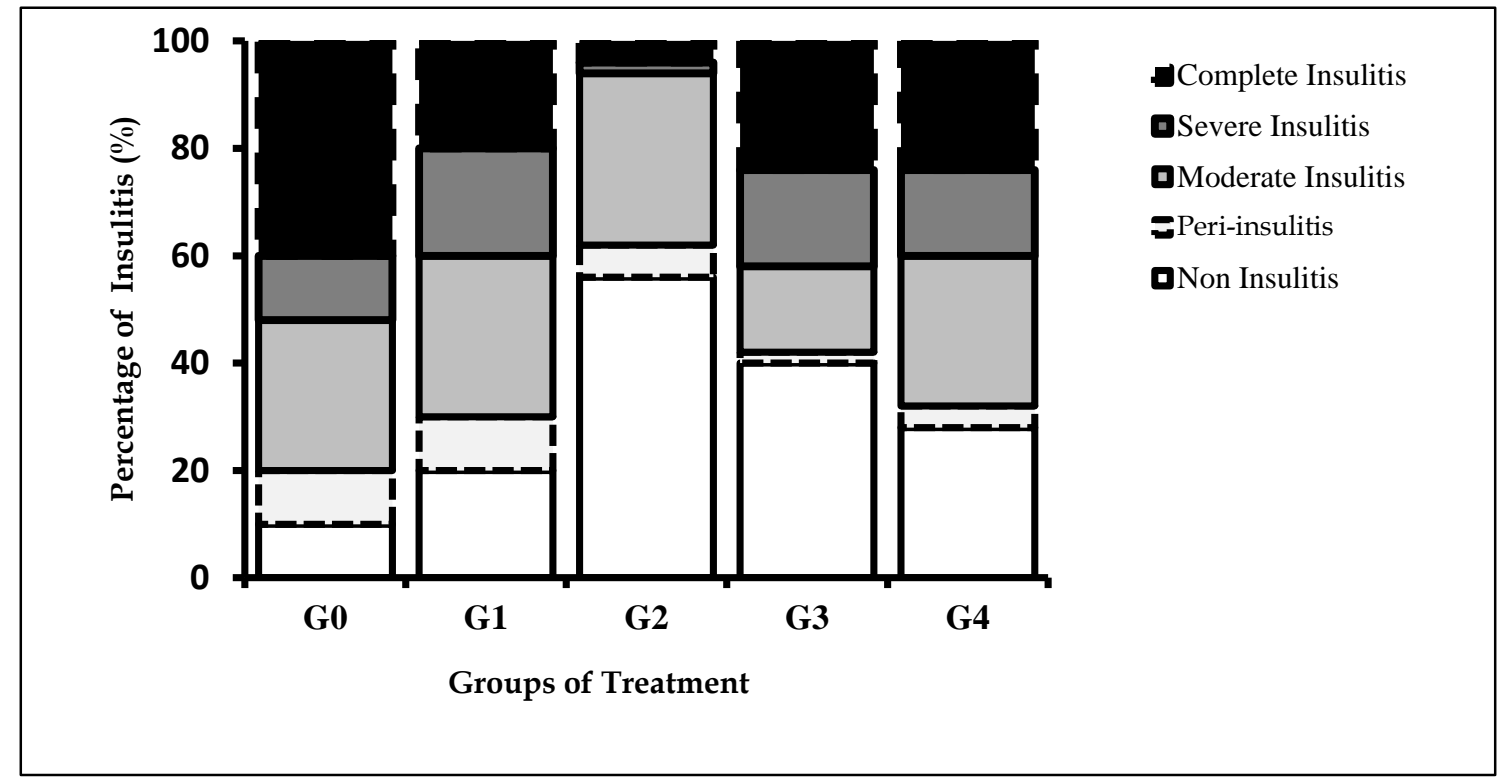

Figure 2. Effect of n-hexane fraction on the insulitis. G0. negative control; G1. positive control (glibenclamide); G2. $57.03 \mathrm{mg} / \mathrm{kg}$ body weight of n-hexane fraction; G3. $114.06 \mathrm{mg} / \mathrm{kg}$ body weight of nhexane fraction; G4. $171.09 \mathrm{mg} / \mathrm{kg}$ body weight of n-hexane fraction.

\section{DISCUSSION}

Our present study demonstrates therapeutic effects of n-hexane fraction of E. fluctuans aerial against blood glucose increase, insulitis reduction, and pancreatic degenerations in alloxan-induced diabetic rats. Insulitis is found not only in people with type 1 diabetes but also in people with type 2 diabetes [4]. Insulitis is characterized by infiltration of lymphocytes in the islet of Langerhans, which is known as an indicator of pancreatic $\beta$-cell damage [2]. In insulitis, pro-inflammatory cytokines are important in inducing cytotoxicity in pancreatic $\beta$-cells. Tumor necrosis factor- (TNF- $\alpha$ ), interleukin-1 (IL1 $\beta$ ), and interferon- (IFN- $\gamma$ ) were proinflammatory cytokines [1,20-21]. Therefore, to prevent diabetes complications, reduce insulitis, and repair insulin-producing pancreatic $\beta$-cells is the right solution in the treatment of diabetes [1-6]. A lot of research shows that compounds derived from plants have the activity to reduce insulitis and regenerate the Islets of Langerhans [7, 22-23]. The glucose-lowering effect of ethanol extracts of aerial E. fluctuans has been reported [13-14], but its effect on reducing insulitis and ameliorating the pancreas has not been reported. Our study focused on evaluating the protective effect of n-hexane fraction of this herb against insulitis in alloxan-induced diabetic rats. The diabetic rats used are stable hyperglycemia. Administration of $n$-hexane fraction for 21 days is known to reduce insulitis and improve pancreatic $\beta$-cell function in alloxan-induced diabetic rats. The reduction in insulitis depends on the dose. The low dose $(57.03 \mathrm{mg} / \mathrm{kg}$ body weight) showed the best insulitis reduction activity and better than glibenclamide.

E. fluctuans is more effective than glibenclamide in reducing insulitis because it contains compounds that can activate multiple pathways for pancreatic $\beta$-cell regeneration by modulating numerous genes or proteins involved in insulin signaling, inflammation, oxidative stress, and apoptosis. Zhang et al [24] stated that the reduction of insulitis was linked to the regeneration of pancreas islet $\beta$-cells. Regeneration of the pancreas is in the form of proliferation and differentiation of pancreas islet $\beta$-cells $[8,25-26]$. Terpenoids are a class of drugs that have been shown to regenerate and improve pancreatic $\beta$-cells function [3]. In this study, 
the n-hexane fraction contains terpenoids and steroids. E. fluctuans is rich in terpenoid compounds (diterpenoid acids and their isovalerate and angelate derivatives, saponins, sesquiterpene lactones and steroids (sitosterol and stigmasterol) [26].

One group of compounds that have been noted have the activity to modulate insulin signaling and pancreatic regeneration is terpenoid [3, 27-29]. Mabhida et al [30] and Shehata et al [31] reported that terpenoids can maintain and ameliorate the ultra-structure of the pancreas by suppressing the production of inflammatory cytokines and activation of erythroid-derived 2-like 2 (Nrf2), a master regulator of intracellular antioxidant transcription when stress oxidative [32-33].

The terpenoid compounds like dihydro-CDDO-trifluoromethyl amide (dh404) has the activity of regenerating the ultra-structure of pancreatic $\beta$-cells through activation of Nrf2 and suppressing inflammatory factors like tumor necrosis factor- $\alpha$ (TNF- $\alpha$ ), interleukin-6 (IL-6), and interleukin 1- $\beta$ (IL-1- $\beta$ ) [34]. The terpenoid compounds modulate the activation of phosphatidyl 3-kinase (P13-K), 5'AMP activated protein kinase (AMPK), and glucose transporters (GLUTs) [28]. GLUTs and P13-K protect pancreatic $\beta$ cells through the proliferation, differentiation, and insulin signaling continuity through regulation of the activity of protein glycogen synthase kinase 3 beta (GSK3 $\beta$ ) [35]. AMPK is a complex protein that builds the $\alpha, \beta$, and $\gamma$ subunits of the pancreas [36]. Steroids (28Nor-22(R)Witha 2,6,23-trienolide) improve blood glucose status and increase insulin levels [37]. In other words, steroids are indirectly involved in the repair of the pancreas. So, the nhexane fraction of $E$. fluctuans aerial modulate insulin signaling and activate genes or proteins involved in pancreatic protection and pancreatic regeneration.

The effect of $n$-hexane fraction on insulitis reduction and pancreatic $\beta$-cell repair of diabetic rats was the first reported. The findings of this study indicate that E. fluctuans aerial is potentially used for diabetes management. However, this study has limitations in terms of not using a single active substance hence that other active ingredients contained in it might affect the results of this study.

The n-hexane fraction has active compounds that have the activity of stimulating insulin secretion, resulting in high insulin levels in the blood. Insulin facilitates the use and uptake of glucose by the liver and muscles, resulting in reduced blood glucose in diabetic rats. It is known that $E$. fluctuans aerial has the activity of ameliorating the islet of Langerhans from damage caused by alloxan and high blood glucose toxicity. Thus, the administration of the n-hexane fraction especially the dose of $57.03 \mathrm{mg} / \mathrm{kg}$ body weight (G2), has the activity of ameliorating islets of Langerhans and increasing the number of $\beta$-cells of the pancreas.

\section{CONCLUSION}

The findings show that aerial E. fluctuans exerted an antidiabetic effect by inhibiting insulitis and repairing pancreatic $\beta$-cell damage in alloxan-induced diabetic rats. Thus, E. fluctuans aerial could be potentially used for diabetes management. However, further research is needed to characterize the active compound and test its safety.

\section{MATERIALS AND METHODS}

\subsection{Reagents and animals}

Alloxan was acquired from Sigma-Aldrich Chemical (St. Louis, MO, USA). Kits for measuring insulin (Rats Insulin (Ins) Elisa Kit, 96T rats, BT LAB, Shanghai Korain Biotech Co. Ltd, China). Caplets glibenclamide $5 \mathrm{mg}$ was aquired from Indofarma (Bekasi, Indonesia). Wistar male rats were obtained from the animal house of Department of Biology Education, Faculty of Tarbiyah and Teacher Training, Institut Agama Islam Negeri (IAIN) Batusangkar, and given pellets and tap water ad libitum. The handling of rats was established under guidelines by the Research Ethics Committee of Faculty of Medicine, Andalas University, Padang, Indonesia (No: 038/KEP/FK/2019).

\subsection{E. fluctuans aerial fractionation}

E. fluctuans aerial was collected from Lima Kaum, Tanah Datar District, West Sumatra, Indonesia, and authenticated by plant taxonomists in the Herbarium of the Department of Biology, Andalas University, Padang (No: 046/K-ID/ANDA/I/2021). E. fluctuans aerial was dried for up to 15 days then grounded and screened. $532 \mathrm{~g}$ of E. fluctuans aerial powder was extracted with ethanol $96 \%$ distillate solvent, using the maceration method. The extract was evaporated and concentrated at $40^{\circ} \mathrm{C}$, using a rotary evaporator (Hei-Vab Core Rotary Evaporator, Germany). Furthermore, $100 \mathrm{~g}$ of the crude extract was dissolved in $96 \%$ ethanol. 
After the viscous extract dissolved, fractionation was carried out using a stratified liquid-liquid method using n-hexane as a solvent. The fractions were then concentrated and kept before being used in the experiment.

\subsection{Induction of hyperglycemia for diabetes experiments}

Before induction, rats with 180-250 g body weight were acclimatized for 3 days and subsequently fasted for 15 hours by depriving food but a water drink was provided continuously. Furthermore, rats were injected with a solution of alloxan in $0.9 \% \mathrm{NaCl}$ with a dose of $125 \mathrm{mg} / \mathrm{kg}$ body weight. Diabetic status was confirmed by measuring the blood glucose 96 hours after injection. The study used rats with blood glucose levels greater than $300 \mathrm{mg} / \mathrm{dL}$.

\subsection{Experimental research design}

Diabetic rats were randomly divided into six groups $(n=5)$ as follows:

- Normal control (GN): normal rats without treatment;

- Negative control (G0): diabetic rats administered with $0.5 \% \mathrm{Na}-\mathrm{CMC}$;

- Positive control (G1): diabetic rats administered with glibenclamide at a dose $0.45 \mathrm{mg} / \mathrm{kg}$ body weight;

- Dose 1 (G2): diabetic rats administered with n-hexane fraction of E. fluctuans aerial at a dose 57.03 $\mathrm{mg} / \mathrm{kg}$ body weight;

- Dose 2 (G3): diabetic rats administered with n-hexane fraction of E. fluctuans aerial at a dose of 114.06 $\mathrm{mg} / \mathrm{kg}$ body weight;

- Dose 3 (G4): diabetic rats administered with n-hexane fraction of E. fluctuans aerial at a dose 171.09 $\mathrm{mg} / \mathrm{kg}$ body weight.

We chose the n-hexane fraction because it showed the best antidiabetic activity when compared to other fractions (ethyl acetate and n-butanol) in the preliminary research. The antidiabetic activity of n-hexane had the lowest $\mathrm{AUC}_{0-180}$ value, the highest percentage of blood glucose reduction, and was statistically significant when compared with the ethyl acetate and n-butanol fractions (data not shown).

The determination of fraction doses was based on preliminary research (data not shown). Glibenclamide and n-hexane fraction were dissolved in Na-CMC $0.5 \%$ and administered orally once a daily for 21 days. Rats had free access of feed and water ad libitum.

\subsection{Measurement of blood glucose}

On the day 0 and 21, fasting blood samples were collected directly from the rats' tail. Then, a glucometer (GlucoDr. AutoTM, Model AGM-4000, Korea) was used to measure blood glucose levels.

\subsection{Measurement of plasma insulin}

At 22 days, the rats were sacrificed and blood was collected by cardiac puncture. Blood was carefully placed in the vacutainer. The blood sample for each treatment was collected by centrifugation ( $5000 \mathrm{rpm}$ for 5 $\mathrm{min}$ ). Insulin concentrations in plasma samples were determined utilizing an ELISA assay with 96T rat insulin assay kits according to the manufacturer's protocol.

\subsection{Pancreatic tissue sampling}

The pancreas was isolated at the end of the experiment from each group. The samples were fixed with ia buffer of $10 \%$ neutral formalin (BNF) before being processed for histopathological examination. The samples were embedded in paraffin and sectioned at $5 \mu \mathrm{m}$ thickness and then stained with hematoxylin-eosin (H\&E) and images were taken by photo microscope (Olympus DP 22, Tokyo, Japan). Pancreatic preparations were observed with an objective magnification of 400x and in 10 different fields of view with at least 10 islets of Langerhans observed.

\subsection{Insulitis Score}

Insulitis scoring was carried out by two different observers. Insulitis grade scores ranged from $0-4$ according to the scoring method as described previously reported method [2, 38; Table 4]. The percentage of insulitis for each islet of Langerhans was calculated. Insulin-secreting islets were scored as no insulitis, periinsulitis, insulitis in each rat [2]. 
Table 4. Scoring categories for insulitis.

\begin{tabular}{cll}
\hline Score & Category of cells & Justification \\
\hline 0 & No necrosis & Noninsulitis \\
1 & Necrosis $<25 \%$ & Peri-insulitis \\
2 & Necrosis $26-50 \%$ & Moderate insulitis \\
3 & Necrosis $51-75 \%$ & Severe insulitis \\
4 & Necrosis $>76 \%$ & Complete insulitis \\
\hline
\end{tabular}

\subsection{Statistical analysis of data}

Data are presented in mean \pm standard error (S.E.M.) for five rats in the individual experimental group. Statistical analyses were performed using SPSS 21 . The hypothesis was then tested by one-way ANOVA. If the significant difference was confirmed, then it was continued with Duncan's New Multiple Range Test $(P<$ 0.05). The percentage of reduction in blood glucose levels was determined by the formula:

$$
\% \text { reduction of blood glucose }=\left(1-\frac{W e}{W c}\right) \times 100
$$

$\mathrm{W}_{\mathrm{e}}$ is the blood glucose concentration in the glibenclamide or fraction treatment, and $\mathrm{W}_{\mathrm{c}}$ is the control of blood glucose concentration [10,39].

Acknowledgments: We thank the head of Integrated Service Unit Basic and Central Laboratory, Andalas University for research facilities. We also thank the Zoology laboratory staff, Biology Education Department, Faculty of Tarbiyah and Teacher Training IAIN Batusangkar for their assistance in carrying out this research. We also thank to Putra Santoso, Ph.D, Department of Biology, Faculty of Mathematics and Natural Science, Andalas University, West Sumatra, Indonesia for his suggestions in preparing this manuscript.

Author contributions: Concept - R.D., D.D., D.H.T., S.S.; Design - R.D., T.H.D., D.D., S.S.; Materials - R.D.; Data Collection and/or Processing - R.D., D.H.T.; Analysis and/or Interpretation - R.D., D.H.T., S.S., D.D.; Literature Search - R.D., D.D., D.H.T., S.S; Writing - R.D., T.H.D.; Critical Reviews - R.D., D.D., D.H.T., S.S.

Conflict of interest statement: There are no conflicts of interest.

Ethics committee approval: Experimental protocols were approved by the Research Ethics Committee of Faculty of Medicine, Andalas University, Padang, Indonesia (No: 038/KEP/FK/2019).

\section{REFERENCES}

[1]. Böni-Schnetzler M, Meier DT. Islet inflammation in type 2 diabetes. Semin Immunopathol. 2019; 41: 501-513. [CrossRef]

[2]. Zhao B, Wu F, Han X, Zhou W, Shi Q, Wang H. Protective effects of acarbose against insulitis in multiple low-dose streptozotocin-induced diabetic mice. Life Sci. 2020; 263(118490): 1-8. [CrossRef]

[3]. Mabhida SE, Dludla P V, Johnson R, Ndlovu M, Louw J, Opoku AR, Mosa RA. Protective effect of triterpenes against diabetes-induced $\beta$-cell damage: An overview of in vitro and in vivo studies. Pharmacol Res. 2018; 137: $179-192$. [CrossRef]

[4]. Lundberg M, Seiron P, Ingvast S, Korsgren O, Skog O. Insulitis in human diabetes: a histological evaluation of donor pancreases. Diabetologia. 2017; 60(2): 346-353. [CrossRef]

[5]. Internation Diabetes Federation. IDF Diabetes Atlas, 9th Edition. 9th ed. Dunia : IDF. Brussels, Belgium. 2019.

[6]. Karakose E, Ackeifi C, Wang P, Stewart AF. Advances in drug discovery for human beta cell regeneration. Diabetologia. 2018; 61(8): 1693-1699. [CrossRef]

[7]. Jangir, RN, Jain G. Evaluation of protective effects of hydroalcoholic extract of Cassia fistula Linn. pod on pancreas in streptozotocin-induced diabetic. Pharmacognosy Res. 2018; 10(2): 205-212. [CrossRef]

[8]. Guney MA, Lorberbaum DS, Sussel L. Pancreatic $\beta$ cell regeneration: to $\beta$ or not to $\beta$. Curr Opin Physiol. 2020; 14: 13-20. [CrossRef] 
[9]. Lau K-M, Lai K-K, Liu C-L, Tam JC-W, To M-H, Kwok H-F, Lau C-P, Ko-C-H, Leung P-C, Fung K-P, Poon, SK-S, Lau CB-S. Synergistic interaction between Astragali radix and Rehmanniae radix in a Chinese herbal formula to promote diabetic wound healing. J Ethnopharmacology. 2012; 141(1): 250-256. [CrossRef]

[10]. Sayeed SR, Ahmed H, Rahman S, Ahmad I. Polyherbal formulation for lowering blood glucose levels : Evaluation of a combination of Foeniculum vulgare and Brassica alba seeds. World J Pharm Pharm Sci. 2015; 4(10): 79-85. [CrossRef]

[11]. Chinsembu KC. Diabetes mellitus and nature's pharmacy of putative antidiabetic plants. J Herb Med. 2019; 15(100230): 1-12. [CrossRef]

[12]. Chaudhuri A, Sharma S. Evaluation of antidiabetic activity of polyherbal formulation in streptozotocin-induced diabetic rats. J Pharm Biosci. 2016; 4(5): 1-6. [CrossRef]

[13]. Hasan MN, Sabrin F, Rokeya B, Khan MSH, Ahmed MU, Matondo A, Billah MdM, Akter, S. Glucose and lipidlowering effects of Enhydra fluctuans extract in cadmium treated normal and type-2 diabetic model rats. BMC Complement Altern Med. 2019; 19(278): 1-10. [CrossRef]

[14]. Delfita.R , Tjong, HD, Dahelmi, D, Suhatri S. Hypoglycemic effects of Enhydra fluctuans aerial extract on alloxaninduced diabetic rats. Journal of Physics: Conference Series. 2021; 1940(1): 1-7. [CrossRef]

[15]. Kumar, SP, Jagannath, PV, Chandra, DS, Prasan N. Hepatoprotective activity of Enhydra fluctuans Lour. aerial parts against $\mathrm{CCl}_{4}$ induced hepatotoxicity in rats. Int J Res Ayurveda Pharm. 2012; 3(6): 893-896. [CrossRef]

[16]. Panigrahi R, Bhatnagar S. Cytotoxic, phytochemical and antioxidant potential of marshy herb Enhydra fluctuans Lour. Vol. 1, International Journal of Ethnobiology and Ethnomedicine. 2015; 1(1). 1-5.

[17]. Dua, TK, Dewanjee, S, Khanra R. Prophylactic role of Enhydra fluctuans against arsenic-induced hepatotoxicity via anti-apoptotic and antioxidant. Redox Rep Commun Free Radic Res. 2016; 11(6): 45-50. [CrossRef]

[18]. Ali R, Billah M, Hassan M, Rahman SM. Enhydra fluctuans Lour : A Review. Res J Pharm Tech. 2013; 6(9): 927-929.

[19]. Sarkar P, Dalal A. Evaluation of Antioxidant Activity of Diplazium esculentum and Enhydra fluctuans of West Bengal. IOSR J Pharm Biol Sci. 2016; 11(6): 45-50. [CrossRef]

[20]. Rabinovitch A, Suarez-Pinzon WL. Cytokines and their roles in pancreatic islet $\beta$-cell destruction and insulindependent diabetes mellitus. Biochem Pharmacol. 1998; 55(8): 1139-1149. [CrossRef]

[21]. Böni-Schnetzler M, Ehses JA, Faulenbach M, Donath MY. Insulitis in type 2 diabetes. Diabetes, Obes Metab. 2008; 10( 4): 201-204. [CrossRef]

[22]. Sunday JJ, Spencer NCO, Kingsley O, Akintola AA, Binyelum N, Favour AO. Possible revival of atrophied islet cells of the pancreas by Vernonia amygdalina in alloxan-induced diabetic rats. J Appl Pharm Sci. 2012; 2(9): 127-131. [CrossRef]

[23]. Umamageswari MS, Karthikeyan TM, Maniyar YA. Antidiabetic activity of aqueous extract of Solanum nigrum Linn berries in alloxan-induced diabetic Wistar albino rats. J Clin Diagnostic Res. 2017; 11(7): 16-19. [CrossRef]

[24]. Zhang C, Todorov I, Lin CL, Atkinson M, Kandeel F, Forman S, Zeng D. Elimination of insulitis and augmentation of islet $\beta$ cell regeneration via induction of chimerism in overtly diabetic NOD mice. Proc Natl Acad Sci USA. 2007; 104(7): 2337-2342. [CrossRef]

[25]. Zhu Y, Liu Q, Zhou Z, Ikeda Y. PDX1, Neurogenin-3, and MAFA: Critical transcription regulators for beta cell development and regeneration. Stem Cell Res Ther. 2017; 8(1): 1-7. [CrossRef]

[26]. Oh YS. Plant-derived compounds targeting pancreatic beta cells for the treatment of diabetes. Evidence-based Complement Altern Med. 2015; 2015: 1-12. [CrossRef]

[27]. Habtemariam S. Antidiabetic potential of monoterpenes: A case of small molecules punching above their weight. Int J Mol Sci. 2018; 19(1): 1-23. [CrossRef]

[28]. Sharma B, Mittal A, Dabur R. Mechanistic approach of anti-diabetic compounds identified from natural sources. Vol. 5, Chemical Biology Letters. 2018; 5(2). 63-99.

[29]. Germoush MO, Elgebaly HA, Hassan S, Kamel EM, Bin-Jumah M, Mahmoud AM. Consumption of terpenoids-rich Padina pavonia extract attenuates hyperglycemia, insulin resistance, and oxidative stress, and upregulates ppary in a rat model of type 2 diabetes. Antioxidants. 2020; 9(22): 1-24. [CrossRef]

[30]. Mabhida SE, Mosa RA, Penduka D, Osunsanmi FO, Dludla P V, Djarova TG, Opuku, AR. A lanosteryl triterpene from Protorhus longifolia improves glucose tolerance and pancreatic beta-cell ultrastructure in type 2 diabetic rats. Molecule. 2017; 22(1252): 1-11. [CrossRef] 
[31]. Shehata AM, Bettio S, Jauch J, Scior T, Scherbaum WA, Ammon HPT. 11-Keto- $\beta$-boswellic acids prevent development of autoimmune reactions, insulitis and reduce hyperglycemia during induction of multiple low-dose streptozotocin (MLD-STZ) diabetes in mice. Horm Metab ResResearch. 2015; 47: 463-9. [CrossRef]

[32]. Fu J, Zheng H, Wang H, Yang B, Zhao R, Lu C, et al. Protective role of Nuclear Factor E2-Related Factor 2 against acute oxidative stress-induced pancreatic $\beta$-cell damage. Oxid Med Cell Longev. 2015; 2015: 1-12. [CrossRef]

[33]. Dludla P V, Muller CJF, Joubert E, Louw J, Essop MF, Gabuza KB, et al. Aspalathin protects the heart against by upregulating Nrf2 expression. Molecules. 2017; 22(129): 1-16. [CrossRef]

[34]. Li S, Vaziri ND, Masuda Y, Hajighasemi-ossareh M, Robles L, Le A, et al. Pharmacological activation of Nrf2 pathway improves pancreatic islet isolation and transplantation. Cell Transplant. 2015; 24(714): 2273-2283. [CrossRef]

[35]. Jiang WJ, Peng YC, Yang KM. Cellular signaling pathways regulating $\beta$-cell proliferation as a promising therapeutic target in the treatment of diabetes. Exp Ther Med. 2018; 16(4): 3275-3285. [CrossRef]

[36]. Rourke JL, Hu Q, Screaton RA. AMPK and Friends: Central regulators of $\beta$ cell biology. Trends Endocrinol Metab. 2018; 29(2): 111-122. [CrossRef]

[37]. Daisy P, Jasmine R, Ignacimuthu S, Murugan E. A novel Steroid from Elephantopus scaber L. an ethnomedicinal plant with antidiabetic activity. Phytomedicine. 2009; 16(2-3): 252-7. [CrossRef]

[38]. Han Z, Tao Y-L, Deng Y-P, Yu J-W, Cai J, et al. Metformin ameliorates insulitis in STZ-induced diabetic mice. PeerJ. 2017; 5: 1-13. [CrossRef]

[39]. Saha M, Rohani S, Rayhana N, Toma IJ, Rana S, Rahmatullah M. An herbal formulation containing Zingiber officinale rhizomes and Allium sativum cloves can increase oral glucose tolerance in mice. Biol Eng Med. 2017; 2(1): 1-3. [CrossRef]

This is an open access article which is publicly available on our journal's website under Institutional Repository at http://dspace.marmara.edu.tr. 